\title{
ПЕРЕДУМОВИ РОБОТИЗАЦІї ПРОЦЕСУ ДОЇННЯ КОРІВ
}

Бугай Тетяна Анатоліївна головний технолог Молочний комплекс «Вільшанське» Двурічанський район, Харківська область ORCID: 0000-0002-9348-5072

E-mail: ksp-vilshana@rambler.ru

Гноєвий Ігор Вікторович доктор сільськогосподарських наук, профресор Харківська державна зооветеринарна академія ORCID: 0000-0003-1350-6898 E-mail: K64.070.02_hdzva@i.ua

Науменко Олександр Артемович
кандидат технічних наук, професор
Харківський національний технічний університет сільського господарства ім. Петра Василенка
ORCID: 0000-0002-9936-3922
E-mail: kaf_mtf@ukr.net
Гноєвий Biктор Іванович
Харківський національний технічний університет сільського господарства ім. Петра Bacиленка
ОRCID: 0000-0001-8585-0095
E-mail: hgzva2902.1936@gmail.com

Робота виконана в умовах молочно-товарного комплексу «Вільшанське» Двурічанського району, Харківської області в 2018-2019 роках, де створено зразковий добробут для 500 корів української чорно-рябої молочної породи. У якості об'єктів для проведення досліджень використовували два доїльні роботи фрірми «GEA» (Німеччина), які обслуговують 120 корів та ферма на 380 корів, яка в 2011 році була реконструйована на безприв'язне боксове утримання корів і їх годівлю з кормового столу, а напування - з типових групових поїлок. Для доїння корів основного стада використали доїльний блок типу «Ялинка» Euroclass 2x12. Впровадженню доїльних роботів має передувати переведення молочного комплексу на ефективну промислову технологію, яке забезпечить молочну продуктивність корів на рівні 10 тис. кг/рік за рентабельності його виробництва 35-50\%. Першочерговою задачею є створення власної повноцінної, стабільної кормової бази на основі пріоритетних кормових культур з метою виробництва з розрахунку на 1 корову, в середньому, 116 ГДжОЕ та організація цілорічно однотипної годівлі кормовими сумішками, складеними за деталізованими нормами годівлі високопродуктивних корів з витратою на 1 и молока в межах 1,12 ГДж ОЕ, у тому числі за рахунок концентрованих кормів 580-638 МДжОЕ. Система вирощування ремонтних телиць має забезпечувати середньодобові прирости їх маси 800 г за весь період вирощування, в тому числі до 6-ти міс. - 890 2, до року - 800 2, старше року - 810 г з витратою кормів на 1 ке приросту маси не більше - 74,24 МДжОЕ, в тому числі концентрованих кормів - 24,36 МДжОЕ. Застосування доїльних роботів не забезпечує підвищення середньодобових надоїв молока у корів, але сприяє зменшенню затрат людської праці, а їх вузька особливість - невідповідність тривалості часу доїння і тривалості часу споживання виділеного комбікорму, що треба мати на увазі і вносити відповідні корективи. Система управління стадом, яка використана на молочно-товарному комплексі «Вільшанське» забезпечує ефрективність використання доїльних роботів за рівня продуктивності корів у 2018 роиі, в середньому 10556 кг та рентабельності його виробництва у межах 34,443,7\% і окупності доїльних роботів 3 роки і 10 місяиів.

Ключові слова: корови, доїння, роботи, організація, технологія.

DOI: https://doi.org/10.32845/bsnau.lvst.2020.1.5

у науковій літературі повідомляється, що одним із основних факторів, що впливають на продуктивність корів і якість молока, є організація процесу доїння і технічна досконалість використаного при цьому доїльного обладнання. В умовах молочно-товарного комплексу «Вільшанське» Двурічанського району, Харківської області в 2018-2019 роках створено зразковий добробут для 500 корів української чорно-рябої молочної породи.

Нині удосконалення процесу виробництва молока проходе за двома основними напрямками - біологічному та технологічному. Оскільки біологічний процес (удосконалення

порід, селекційний відбір і добір тварин з урахуванням їх продуктивності і маси, швидкості доїння і ін.) проходе повільно і на протязі зміни багатьох поколінь тварин, більш актуального значення набуває другий напрямок виробництва молока - технологічний. Він зв'язаний 3 механізацією, автоматизацією та інформатизацією виробничих процесів. Як свідчать наукові публікації, обидва ці напрямки (біологічний і технологічний) $\epsilon$ взаємодоповнюючими. Тут також має велике значення організація виробничих процесів, яка часто зветься процесом управління стадом і виробництвом молока [14, 
16].

Одним із визначних досягнень технологічного розвитку у молочному скотарстві за останні роки стала роботизація процесу доїння корів. Вона швидкими темпами розповсюджується в економічно розвинених країнах Світу. В Україні господарі, керівники молочних ферм і комплексів, маючи певні фінансові можливості також зацікавленні у впровадженні доїльних роботів, проте їх висока вартість (один блок на 60 дійних корів коштує в межах 14 млн. гривень) закономірно викликає сумніви щодо реальності їх швидкої окупності. Безумовно, що для впровадження доїльних роботів виробничникам потрібна, окрім рекламних проспектів, інформація, що базується на результатах наукових досліджень і передового досвіду, одержаних в конкретних виробничих умовах України.

$\mathrm{Ha}$ думку багатьох авторів, впровадження прогресивного обладнання дає можливість найбільш повно реалізувати генетичний потенціал тварин, зберегти здоров'я як корів, так і доярів, одержати молоко високої якості [1, 4, 7, 18 , 24]. Нині найбільш перспективним напрямком в механізації доїння корів є застосування доїльних роботів, які в автоматизованій системі доїння виконують багато функцій, які раніше були покладені на доярок [5, 8, 13]. Вони підготовляють вим'я перед підключенням доїльного апарату, знаходять дійки і підключають до них доїльний апарат, своєчасно його знімають, дезінфікують резину доїльних стаканів. Ці роботи подають сигнали спеціальним воротам для вилучення проблемних корів, замірюють кількість надоєного молока, його кислотність, температуру, кількість соматичних клітин і т. ін., крім цього, доїльні роботи оцінюють стан кожної з четвертей вим'я і своєчасно виявляють ознаки маститу $[9,10,21]$. Ефеекивність використання роботизованих систем для доїння корів полягає не тільки в усуненні ручної праці, але і в створенні молочному стаду найбільш сприятливих умов з точки зору їх фізіології та конституції [19]. Використання роботів для доїння корів сприяє виникненню практично нової технології, основна суть якої полягає в самообслуговуванні тварин [2, $12,15]$. Вона залишає корові право на свободу вибору часу і частоти відвідування доїльного боксу. Дослідження вказують, що тварини досить швидко звикають до доїння роботом і самостійно відвідують доїльний бокс.

У науковій літературі також часто відзначається проблема високої вартості доїльних роботів. Щоб в певній мірі ї̈ мінімізувати, рекомендується їх застосовувати при досягненні продуктивності корів 6,5 тис. кг молока/рік і більше. На нашу думку, таке вирішення проблеми не $є$ конкретним, бо не враховується рівень рентабельності виробництва молока, його вартість, товарність і реалізаційна ціна.

Слід також враховувати, що природно-кліматичні умови України суттєво відрізняються від Європейських. Необхідно враховувати також значно нижчий рівень економічного розвитку аграрного сектору. В Україні і в більшості країн Європи різна кормова база, яка також відрізняється за хімічним складом основних кормів. В Україні практично не функціонує ринок кормів, та значно нижча державна підтримка аграрного сектору, тому на шляху впровадження доїльних роботів існує багато ризиків, які вимагають наукового вирішення в конкретних умовах господарювання в Україні [3]. у цілому, у науковій літературі в більшій мірі обговорюється принцип роботи доїльних роботів та технічні умови кращого їх використання і мало приділяється уваги гарантії господарств від фінансових збитків при застосуванні такої техніко-технологічної новації. Саме такі проблеми мають бути вирішенні в наукових дослідженнях, що плануються [11].

Метою наукових досліджень було обґрунтування основних організаційних складових технології застосування доїльних роботів на молочних комплексах України.

Для виконання мети ставилися задачі науково обґрунтувати такі системи:

1. Створення власної повноцінної, стабільної кормової бази, науково обгрунтувати і впровадити високоякісну годівлю корів, які забезпечують ефективне застосування доїльних роботів.

2. Утримання корів у добробуті, що є обов'язковою умовою ефективного використання доїльних роботів.

3. Вирощування ремонтних телиць 3 метою одержання високопродуктивного молочного стада.

4. Техніко-технологічне застосування доїльних роботів і якість молока.

5. Наукове обґрунтування системи управління стадом.

Матеріали та методи досліджень. Дослідження проведені на молочному комплексі ПСП «Вільшанське» Двурічанського району Харківської області в 2018-2019 роках.

У якості об'єктів для проведення досліджень використано два доїльних роботи фірми GEA «Німеччина», які обслуговують 120 корів, та ферма на 380 корів, яка в 2011 році була реконструйована для безприв'язного боксового утримання, годівлі корів з кормових столів за цілорічно однотипною системою та напування з типових групових поїлок. Для доїння корів на основній фермі використовується доїльний блок типу «Ялинка» Euroclass $2 \times 12$.

Матеріалом для висновків і узагальнень слугували дані комп'ютерів доїльних роботів, лабораторні журнали, квартальні і річні звіти про результати виробничої і економічної діяльності господарства, первинного зоотехнічного обліку, якості кормів і молока. Інші необхідні показники визначались в спеціалізованих і сертифікованих лабораторіях.

Результати досліджень. Кормова база, безумовно, $€$ основою поступального розвитку тваринницького господарства, в якому утримують високопродуктивну велику рогату худобу [23]. Що стосується високопродуктивного молочного комплексу, де планується застосування доїльних роботів, то вона має такі ж особливості, як і при використанні типового доїльного залу типу «Ялинка», стосовно якого робилась реконструкція молочної фрерми в ПСП «Вільшанське».

Нині основна вимога до кормової бази молочного комплексу, де використовуються доїльні роботи, полягає в тому, що вона має відповідати потребам цілорічно однотипної годівлі високопродуктивних корів з використанням кормових сумішок на основі пріоритетних для господарства кормів. Корми мають бути високоякісними, відповідати вимогам діючих ДСТУ. У рецепти кормових сумішок доцільно включати кормові добавки зарубіжного виробництва, наприклад, Avantix intens 80, Avavit M Longi, пропіленгліколь 
та інші, а також білкові і мінеральні добавки вітчизняного виробництва - соняшникову і соєва макуху та шроти, монокальцій фоссрат та ін. [20, 22].

Цілорічно однотипна годівля корів сумішками, складеними з пріоритетних кормів, з кормового столу на молочному комплексі «Вільшанське», безумовно, стала наслідком корінних змін у всій системі виробництва і використання кормів. Зокрема, за рекомендаціями Інституту тваринництва НАAН [3] були розширені площі посіву під багаторічні трави, кукурудзу на зерно і силос, під сою, впроваджена ефективна технологія консервування плющеного зерна кукурудзи підвищеної вологості, технологія заготівлі сінажу з люцерни підвищеної вологості, технологія заготівлі сінажу з люцерни за вологості вихідної сировини 58-60\% з використанням біологічних консервантів, заготівля зерно-сінажу і силосу з підвищеним вмістом сухої сировини із злако-бобових сумішок ярих зернофуражних культур. У цілому, вся система кормозабезпечення була переведена на застосування ефективних кормових культур (кукурудза на зерно і силос, багаторічні злако-бобові трави на сіно, сінаж, злако-бобові сумішки ярих зернофуражних культур на зерно сінаж і силос з підвищеним вмістом сухої речовини, а серед зернових культур - пшениця, соя, ячмінь та інші).

Вирощування ремонтного молодняку. В організаційній системі створення високопродуктивного стада корів, безумовно провідне місце належить технології вирощування ремонтного молодняку. Для цього побудували новий телятник ангарного типу з полегшених металоємних конструкцій з рухомими боковими шторами замість вікон. Новий телятник, не будучи типовим, забезпечує сприятливі умови для росту і розвитку ремонтних теличок. Зокрема, кожна теличка до 2-місячного віку має окрему клітку площею $2 \mathrm{~m}^{2}$ з використанням глибокої солом'яної підстилки, яка змінюється кожні 7 діб [17].

Конструкція приміщення забезпечує сприятливі санітарно-гігієнічні умови утримання телят та мікроклімат. Зокрема, інтенсивність освітлення 80-130 Люкс за тривалості > 10 годин. Відносна вологість повітря $є$ низькою - 60-80\% за достатності кисню. Наявність аміаку у повітрі < $300 \mathrm{~cm}^{3} / \mathrm{M}^{3}$, сірководню $<5 \mathrm{~cm}^{3} / \mathrm{M}^{3}$, повітрообмін постійний, а максимальна швидкість повітря не більше 0,1 м/с, температурна різниця (зовнішня/внутрішня температура) < $5^{\circ} \mathrm{C}$.

Температура повітря у такому приміщенні залежить від температури навколишнього середовища. За мінусових температур у приміщенні завжди тепліше на 3-50 C.

Дослідження показали, що у ранній період життя дуже важливо привчити телят до раннього споживання початкового раціону (зерносуміш концентрованих кормів) 3 високими смаковими якостями. Такий раціон має важливе значення для забезпечення можливості раннього припинення випоювання молока, розвитку рубця, поступового переходу до звичайних кормів, які застосовуються у годівлі корів.

у перші 3 тижні телята тільки привчаються споживати зерновий корм. Суттєве збільшення споживання початкового раціону відбувається на п'ятому тижні, коли вони здатні поїдати такий корм в межах 300г/добу. Для досягнення високої інтенсивності росту телиць важливо, щоб вони на 12-му тижні життя були здатні спожити 1,6 кг/добу такого корму.

Важливо також, щоб початковий раціон складався 3 суміші дерті концентрованих кормів, зерна кукурудзи, БВМД на основі соєвого шроту, а також патоки у невеликій кількості у якості смакового засобу. Така суміш стимулює поступове закриття кормового жолобу шлунку телят, розвиток стінок рубця та заселення його мікрофлорою. Таким чином, телята раніше стають здатними до перетравлювання об'ємистих кормів за допомогою популяції бактерій, що заселяють рубець. Використання початкового зернового раціону можна розпочати через 4 дні після народження і продовжувати до 4-місячного віку. Згодовування високоякісного сіна розпочинається 3 6тижневого віку.

у ПСП «Вільшанське» телята після досягнення 2місячного віку переводяться в інші приміщення, де безприв'язно утримуються до 6-місячного віку у загонах по 10-12 голів за норми площі 2,35 м² /голову з використанням групових поїлок і роздаванням кормосумішки на кормовий стіл.

Молодняк старше 6 місяців утримується у секціях по 60 голів з індивідуальними боксами - клітками розміром 1,50 x 0,9 м. Годівля проводиться повнораціонною сумішкою, напування 3 групових поїлок довжиною 2 м, обладнаних підігрівом.

Внаслідок зміни технологій вирощування племінних телиць покращуються показники господарської діяльності (табл. 1).

Характеристика показників вирощування племінних телиць в ПСП «Вільшанське» за останні 3 роки

\begin{tabular}{|l|c|c|c|c|c|}
\hline \multicolumn{1}{|c|}{ Показники } & \multirow{2}{*}{ Од. виміру } & \multicolumn{4}{|c|}{ Роки } \\
\cline { 3 - 7 } & & 2016 & 2017 & 2018 & 2018 до 2016, \% \\
\hline Кількість тварин & гол. & 619 & 630 & 571 & 92,2 \\
\hline Середньодобовий приріст & г & 712 & 723 & 797 & 111,9 \\
\hline у т.ч.: до 6 місяців & г & 778 & 754 & 887 & 114,0 \\
\hline до 1 року & г & 681 & 828 & 803 & 117,9 \\
\hline ст. 1 року & г & 676 & 654 & 811 & 120,0 \\
\hline Використання кормів на один ц приросту & ГДжОЕ & 10,5 & 7,9 & 7,4 & 70,6 \\
\hline Використання концентрованих кормів на один ц приросту & ГДжОЕ & 3,5 & 2,6 & 2,4 & 68,5 \\
\hline Затрати праці на ц приросту & люд./год & 8,73 & 7,59 & 7,31 & 83,7 \\
\hline
\end{tabular}

Система вирощування ремонтних телиць, що застосована на молочному комплексі «Вільшанське», також забезпечує їм достатньо високий розвиток, який відповідає вимогам стандарту для породи і осіменіння їх у віці 13-14 місяців, що має суттєве економічне значення. 


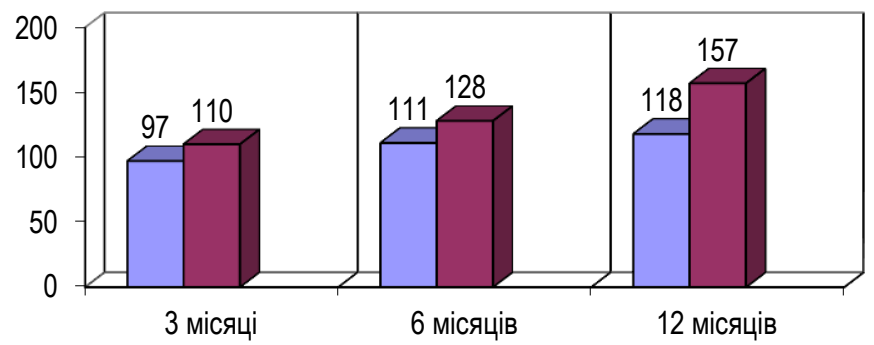

口Висота в холці, см

口Обхват тулуба за лопатками, см

3 місяц

6 місяців

12 місяців

\section{Рис 1. Показники розвитку телиць у залежності від віку на молочному комплексі «Вільшанське» в 2018 році}

Дані рисунку 1 свідчать, що на досвіді роботи молочного комплексу «Вільшанське» можна переконатись в реальній можливості мати у 13-ти місячному віці телиць української чорно-рябої молочної породи масою 364 кг і одержати від них телят у віці 22 місяці і таким чином суттєво зменшити при цьому витрати на їх вирощування.

Доїння корів. Досвід роботи молочного комплексу «Вільшанське» свідчить, що роботизовано система доїння корів добре пристосована до потреб тварин. Якщо в перший день корів практично «заштовхували» в бокс, то на другийтретій день доїння для корів стало привичним явищем, а даванка концентрованих кормів, яку тварини одержували під час доїння, зумовила доїння для них привабливим.

Кожного ранку здійснюється контроль - комп'ютер видає дані про корів, які не доїлися на протязі останніх 12 годин. Серед них, за звичай, корови, які недавно отелились, або готовляться до запуску, тому приходилось їх підганяти.

Не дивлячись на високі інвестиції, використання систем добровільного доїння роботами дає багато переваг, основні з яких - мінімізація людського фактору. Доїльні роботи призвані автоматизувати найбільш відгодівельний і трудомісткий процес при доїнні корів. Роботи для автоматизованої системи доїння виконують практично всі необхідні при доїнні функції: обробляють вим'я до і після доїння, проводять попереднє доїння, надівають і знімають доїльні стакани дезінфікують соскову резинку, заміряють надій молока і ін. Доїльні роботи також дають можливість оцінювати стан кожної четверті вимені і своєчасно виявляти ознаки маститу. Ефективність використання роботизованих систем для доїння корів також заключається не тільки у відсутності ручної праці, але і у створенні добробуту для самих тварин. Корові надається свобода вибору строку і частоти відвідування доїльного боксу, кожна тварина обслуговується у відповідності з своїми добовими ритмами.

У сучасних умовах господарювання впровадження прогресивних технологій виробництва молока на основі безприв'язного способу утримання корів і добровільної роботизованої системи доїння може забезпечити підвищення ефрективності виробництва за високої якості молока (табл. 2).

Таблиця 2

Показники білка і жиру молока корів молочного комплексу «Вільшанське» у 2019 році за двома технологіями доїння, $\mathrm{n}=10$

\begin{tabular}{|c|c|c|c|}
\hline Показники & $\mathrm{M} \pm \mathrm{m}$ & Критерій достовірності, $\sigma$ & Коефіцієнт варіації, Cv,\% \\
\hline \multicolumn{4}{|c|}{ Молочний блок, I лактація } \\
\hline Жир, \% & $3,59 \pm 0,03$ & 0,08 & 2,34 \\
\hline Білок, \% & $3,11 \pm 0,01$ & 0,03 & 0,99 \\
\hline \multicolumn{4}{|c|}{ Молочний блок, II лактація } \\
\hline Жир, \% & $3,62 \pm 0,04$ & 0,14 & 3,74 \\
\hline Білок, \% & $3,12 \pm 0,01$ & 0,04 & 1,16 \\
\hline \multicolumn{4}{|c|}{ Молочний блок, III лактація } \\
\hline Жир, \% & $3,58 \pm 0,05$ & 0,16 & 4,42 \\
\hline Білок, \% & $3,15 \pm 0,02$ & 0,06 & 2,03 \\
\hline \multicolumn{4}{|c|}{ Доїльний робот, I лактація } \\
\hline Жир, \% & $3,37 \pm 0,02$ & 0,05 & 1,42 \\
\hline Білок, \% & $3,12 \pm 0,02$ & 0,05 & 1,66 \\
\hline \multicolumn{4}{|c|}{ Доїльний робот, II лактація } \\
\hline Жир, \% & $3,51 \pm 0,03$ & 0,10 & 2,93 \\
\hline Білок, \% & $3,15 \pm 0,02$ & 0,05 & 1,70 \\
\hline \multicolumn{4}{|c|}{ Доїльний робот, III лактація } \\
\hline Жир, \% & $3,64 \pm 0,11$ & 0,16 & 4,27 \\
\hline Білок, \% & $3,17 \pm 0,02$ & 0,02 & 0,67 \\
\hline
\end{tabular}

He дивлячись на значну капіталоємність, роботизовано система виробництва молока, що застосовується на молочному комплексі «Вільшанське», вирішує задачі зниження затрат і підвищення надоїв молока, про що свідчить короткий строк окупності молочних роботів - 3 роки і 10 місяців [6].

Велике значення в цьому аспекті було впровадження цілорічно однотипної годівлі тварин 3 використанням біологічно повноцінних кормових сумішок. Ці та інші заходи дали змогу при умові зменшення поголів'я корів майже на $30 \%$ збільшити валове виробництво молока в 1,4 раза. По мірі збільшення обсягів виробництва молока господарство стало більше використовувати кормів, проте витрати їх 3 розрахунку на 1 ц продукції, навпаки, знизилися на 10\%, зменшились також витрати людино-годин з розрахунку на 1 ц виробленого молока. 
Система управління стадом. Завдяки всеохоплюючому й якісному менеджменту $€$ можливість виділити економічно значимі параметри управління стадом. Тут одним із важливих показників $є$ втрата тварин. Доктори І.Штайнхофель і Ш. Пахс [15] наводять орієнтовні значення найвищих меж втрат тварин у різні вікові періоди: під час народження і до 48 годин - 8\%, телиці, корови - 5\%, 1-56 й день життя - 5\%, 3-6-й місяць життя - 2\%, старше 7-го місяця життя - 1\%. Якщо в господарстві ці показники вищі, слід шукати пояснення невиправданим витратам.

Здоров'я тварин - головна складова створення високопродуктивного стада. Основною причиною великих відсотків втрат упродовж періоду вирощування $\epsilon$ захворювання телят. Постановка діагнозів, час виникнення захворювання, тривалість і метод лікування, а також використання медикаментів та додаткових речовин - усе це має бути складовою частиною обліку і менеджменту стада.

Ріст $€$ визначальним показником продуктивності телят в період їх розвитку та потенціальної продуктивності дорослих тварин в майбутньому. Він також дає інформацію про те, наскільки успішною є годівля (конверсія корму) на цьому етапі виробництва. Контроль росту починається 3 визначення маси тіла тварини на момент народження. Потім визначають масу тварин в 3 місяці, 6 місяців, 12 місяців і у віці старше 1 року з обов'язковим визначенням кількості використаних кормів, в т.ч. концентрованих, з розрахунку на 1 ц приросту маси.

Зокрема, у ПСП «Вільшанське» затрати на вирощування однієї голови телиць старшого віку чи нетелей складають 900 грн./міс. Кожен рік у стадо вводиться у середньому, 150 голів первісток. Перетримка цього поголів'я перед отеленням усього лише на місяць зумовлює додаткові витрати коштів на суму 135 тис. грн. За старої технології вирощування телиць, коли термін утримання молодняку був більшим на 10 місяців, зайві витрати коштів досягали 1,35 млн. грн., що переносилось на вартість молока. Зазначені розрахунки переконливо свідчать про доцільність широкого застосування нових технологій вирощування племінних телиць у виробництві і управління їх вирощуванням.

У систему управління стадом входять також важливі питання, як відтворна здатність тварин, споживання корму, селекція тварин, виявлення тічки та контроль стану здоров'я тварин, електронне розпізнавання кожної тварини, тощо, проте вони не такі впливові, порівняно з вищезазначеними.

Висновки. Підсумовуючи вищезазначене, $€$ можливість визначити основні організаційні складові технології ефективного використання доїльних роботів на молочних комплексах України.

1. Впровадженню доїльних роботів має передувати організація на молочних комплексах власної ефрективної і стабільної кормової бази на основі пріоритетних кормових культур та організація цілорічно однотипної годівлі корів кормовими сумішками з кормового столу з витратами на 1 ц надоєного молока в межах 1,12 ГДжОЕ, в тому числі за рахунок концентрованих кормів 580-638 МДжОЕ.

2. Система утримання корів має бути безприв'язною боксовою, з вільним доступом до корму, води і доїльного роботу і забезпечувати продуктивність корів в межах 10 тис. кг молока/корову/рік за рентабельності його виробництва в межах $35-50 \%$.

3. Система вирощування ремонтних телиць має забезпечувати середньодобові прирости їх маси 800 г за весь період вирощування, в тому числі до 6-ти міс. - 890 г, до року - 800 г, старше року - 810 г з витратою кормів на 1 кг приросту маси не більше - 74,24 МДжОЕ, в тому числі концентрованих кормів - 24,36 МДжОЕ.

4. Застосування доїльних роботів не забезпечує підвищення середньодобових надоїв молока у корів, але сприяє зменшенню затрат людської праці, порівняно 3 доїльним блоком типу «Ялинка» Euroclass 2x12, а їх вузька особливість - невідповідність тривалості часу доїння і тривалості часу споживання виділеного комбікорму, що треба мати на увазі і вносити відповідні корективи.

5. Система управління стадом, яка використана на молочно-товарному комплексі «Вільшанське» забезпечує есрективність використання доїльних роботів за рівня продуктивності корів в 2018 році, в середньому, 10556 кг та рентабельності його виробництва в межах $34,4-43,7 \%$ і окупності доїльних роботів 3 роки і 10 місяців. 


\section{Список використаної літератури:}

1. Беляева Н.В. Принципы работы роботизированной системы доения коров в СПК «Глинский». Вестник биотехнологии. 2016. №1, С. 1.

2. Виницкий С., Романюк В., Савиных П. Эффективность применения доильных роботов на семейных фермах Польши. Аграрная наука Евро-Северо-Востока. 2014. № 4 (41), С. 52-56. 2009. $368 \mathrm{c}$

3. Гноєвий В.І., Головко В.О., Трішин О.К, Гноєвий І.В. Годівля високопродуктивних корів : [посібник]. Х. : Прапор,

4. Кирсанов В.В., Павкин Д.Ю., Цымбал А.А. Результаты обработки экспериментальных данных с роботов доения по четвертям вымени. Инновации в сельском хозяйстве. 2015. №4 (14), С. 122-128.

5. Кормановский Л.П., Иванов Ю.А., Текучев И.К. и др. Тенденции применения доильных роботов. Техника и оборудование для села. 2008. № 8. С. 36-38.

6. Лебединський В.І., Бугай Т.А., Гноєвий І.В., Гноєвий В.І., Трішин О.К. Наукові і практичні складові технології застосування доїльних роботів на молочному комплексі ПСП «Вільшанське». Ветеринарія, технології тваринництва та природокористування : Науково-практичний журнал. 2019. № 3. С. 185-193. doi: 10.31890/vttp.2019.03.25.

7. Легощин Г., Бильков В., Анищенко А. Сравнительная эффрективность технологий производства молока на фермах с доением в стойлах, в доильных залах и на установках добровольного доения (роботах). Молочное и мясное скотоводство. 2013. № 4. С. 1-5.

8. Маклахов А.В., Жильцов В.И., Никитин Л.А., Углин В.К., Никифоров В.Е. Сравнительная оценка экологической эффрективности использования доильных роботов в ООО «Покровское» Вологодской обл. Экономика и экологические науки. 2017. Вып. 5 (40). С. 1-15.

9. Миронова Т., Муромцев А. Продуктивность и заболеваемость маститом коров при использовании роботизированной и машинной системы доения. Молочное и мясное скотоводство. 2013. № 35. С. 30-31.

10. Науменко О.А. Бойко И.Г. Роботизация процессов доения коров - путь к энергосбережению. Науковий вісник ТДАТУ. 2016. Вип. 1. Т. 3. С. 19-24.

11. Палій Андр., Палій Анат. Техніко-технологічні інновації у молочному скотарстві : Монографія. Х. : Міськдрук, 2019. 324 c.

12. Соболев Н. Роботы дояры - на Вологодской земле. Животноводство России. 2008. № 1. С. 44-46.

13. Суровцев В.Н., Никулина Ю.Н. Оценка экологической эфффективности инновационных технологий доения и содержания молочного стада. Молочное и мясное скотоводство. 2013. № 1. С. 2-5.

14. Тараторкин В.М., Самраханов Т.Г., Абрашкин П.А. Роботизация молочного скотоводства устойчивый тренд. Эффрективное животноводство. 2017. № 1. С. 9-13.

15. Тимощенко В. Музыка А. Что нужно знать о доильных роботах. Белорусское сельское хозяйство. 2016. № 4. C. 13-14. : http://agriculture.by/articles/zhivotnovodstvo/chto-nuzhno-znat-o-doilnyh-robotah

16. Травецкий М. «Астарта-Киев» планирует роботизировать собственные фермы : http://milkua.info/ru/post/astarta-kiev-planiruet-robotizirovat-sobstvennye-fermy.

17. Удосконалення технологї̈ утримання племінних телиць як фактор підвищення економічних показників виробництва молока на молочних комплексах. Лебединський В. І., Бугай Т. А., Гноєвий В. І., Гноєвий І. В., Трішин О. К. Ветеринарія, технології тваринниитва та природокористування : Науково-практичний журнал. 2018. № 2. С. 150 154. doi: 10.31890/vttp.2018.02.39. 2019. 4 c

18. Штайнхофель Ш., Пахе Ш. Менеджмент стада у вирощуванні телят. К. : Товариство «Аграр Медієн Україна»,

19. Экстерьер коров черно-пестрой породы на фермах с интенсивными технологиями. Маклахов А.В., Абрамова Н.Н., Бургомистрова О.Н. и др. Главный зоотехник. 2016. № 12. С. 23-28.

20. Fodder crops as promising sources of biologically active compounds in industrial livestock breeding. Gnoevoy V., Hnoievyi I., Danilova T., Prudnykov V. at all. Agricultura, alimentaria, piscaria et zootechnica. 2018. 341 (46). Szczecin. P. 1318.

21. GEA Monobox Uniquely efficient - automated milking at any time / GEA Farm Technologies GmbH, 2019.: https://www.gea.com/en/binaries/1602017_Monobox_LowRes_GB_529862_tcm11-31184.pdf.

22. Gnoevoy V., Hnoievyi I., Kotets H., Pastukhov V., Melnyk V. Productive and energetic evaluation of growing corn and soya mixture for silage. Scientific papers animal sciences. - Seria zootehnie. 2017. University of Applied Life sciences and Environment. Romania. P. 372-376.

23. Kandyba V., Gnoevoy V., Hnoievyi I. et al. Innovative, soil-energysaving technology of the high valuable feeding and comfortable housing of highly productive animals for the modern farms and complexes of the XXI century : Monograph. X. : Стиль-Издат, 2015. 332 p.

24. Kutchenrajter V. and Grif V. B мире доильной техники : перевод с немецкого. http://mcxconsult.ru/page2309072009.

\section{References:}

1. Belyaeva, N., 2016. Principy` raboty' robotizirovannoj sistemy` doeniya korov v SPK «Glinskij» [Principles of work of the robotic system of milking of cows in SPK «Glinsky»]. Vestnik biotexnologii, issue 1, pp. 1.

2. Viniczkij, S., Romanyuk, V. and Saviny'x, P., 2014. E'ffektivnost' primeneniya doil'ny'x robotov na semejny'x fermax Pol'shi [The effectiveness of milking robots on family farms in Poland]. Agrarnaya nauka Evro-Severo-Vostoka, issue 4, pp. 52- 
56.

3. Gnoevoj, V. I., Holovko, V. O., Hnoievyi, I. V. and Trishyn, O.K., 2009. Hodivlia vysokoproduktyvnykh koriv [Feeding high milk cows]. Kh: Prapor, $368 \mathrm{p}$.

4. Kirsanov, V. V., Pavkin, D. Y. and Cy 'mbal, A. A., 2015. Rezul'taty' obrabotki e'ksperimental'ny'x danny'x s robotov doeniya po chetvertyam vy'meni [Results of processing experimental data from milking robots in quarters of the udder]. Innovacii $v$ sel'skom xozyajstve, issue 4, pp. 122-128.

5. Kormanovskij, L. P., Ivanov, Y. A. and Tekuchev, I. K., 2008. Tendencii primeneniya doil'ny’x robotov [Milking Robot Trends]. Texnika i oborudovanie dlya sela, issue 8, pp. 36-38.

6. Lebedynskyi, V., Buhai, T., Gnoevoj, V. and Hnoievyi, I., 2019. Naukovi i praktychni skladovi tekhnolohii zastosuvannia doilnykh robotiv na molochnomu kompleksi PSP «Vilshanske [Scientific and practical components of technologies of milking robots application on milking complex of PSP «Vilshanske»]. Veterynariia, tekhnolohii tvarynnytstva ta pryrodokorystuvannia, issue 3, pp. 185-193. doi: 10.31890/vttp.2019.03.25

7. Legoshhin, G., Bil'kov, V. and Anishhenko, A., 2013. Sravnitel'naya e'ffektivnost' texnologij proizvodstva moloka na fermax $s$ doeniem $v$ stojlax, $v$ doil'ny'x zalax i na ustanovkax dobrovol'nogo doeniya (robotax) [Comparative efficiency of milk production technologies on farms with milking in stalls, in milking parlors and on voluntary milking installations (robots)]. Molochnoe i myasnoe skotovodstvo, issue 4, pp. 1-5.

8. Maklaxov, A.V., Zhil'czov , V.I., Nikitin, L.A. and et al., 2017. Sravnitel'naya ocenka e'konomicheskoj e'ffektivnosti ispol 'zovaniya doil'ny' $x$ robotov v 000 "Pokrovskoe" Vologodskoj oblasti [Comparative assessment of the environmental efficiency of the use of milking robots in Pokrovskoye LLC, Vologda Oblast]. Voprosy' territorial'nogo razvitiya, issue 5, pp. 1-14.

9. Mironova, T. and Muromcev, A., 2013. Produktivnost' i zabolevaemost' mastitom korov pri ispol'zovanii robotizirovannoj i mashinnoj sistemy' doeniya [Productivity and incidence of mastitis in cows using a robotic and machine milking system]. Molochnoe i myasnoe skotovodstvo, issue 35, pp. 30-31.

10. Naumenko, O. and Bojko, I., 2016. Robotizaciya processov doeniya korov - put' k e'nergosberezheniyu [Robotization of milking cows - a way to save energy]. Naukovij visnik TDATU, issue 3, pp. 19-34.

11. Palii, Andrew and Palii, Anatoliy, 2019. Tekhniko-tekhnolohichni innovatsii u molochnomu skotarstvi [Technical and technological innovations in dairy cattle: Monograph]. Kh. : Miskdruk. 324 p.

12. Sobolev, N., 2008. Roboty' doyary' - na Vologodskoj zemle [Milking robots - on Vologda land]. Zhivotnovodstvo Rossii, issue 1, pp. 44-46.

13. Surovcev, V. and Nikulina, Y., 2013. Ocenka e'kologicheskoj e'ffektivnosti innovacionny'x texnologij doeniya i soderzhaniya molochnogo stada [Environmental performance assessment of innovative milking technologies and dairy herd maintenance]. Molochnoe i myasnoe skotovodstvo, issue 1, pp. 2-5.

14. Taratorkin, V., Samraxanov, T. and Abrashkin, P., 2017. Robotizaciya molochnogo skotovodstva ustojchivy'j trend [Robotization of dairy cattle steady trend]. E'ffektivnoe zhivotnovodstvo, issue 1, pp. 9-13.

15. Timoshhenko, V. and Muzy'ka, A., 2016. Chto nuzhno znat' o doil'ny`x robotax [What you need to know about milking robots]. Belorusskoe sel'skoe xozyajstvo, issue 4, pp. 13-14. Retrieved from: http://agriculture.by/articles/zhivotnovodstvo/chto-nuzhno-znat-o-doilnyh-robotah.

16. Travecz'kij, M. «Astarta-Kiev» planiruet robotizirovat' sobstvenny'e fermy'[Astarta-Kiev plans to robotize its own farms]. Retrieved from: http://milkua.info/ru/post/astarta-kiev-planiruet-robotizirovat-sobstvennye-fermy.

17. Lebedynskyi, V., Buhai, T., Gnoevoj, V. and Hnoievyi, I., 2018. Udoskonalennia tekhnolohii utrymannia pleminnykh telyts yak faktor pidvyshchennia ekonomichnykh pokaznykiv vyrobnytstva moloka na molochnykh kompleksakh [Improvement of technology of keeping of breeding heifers as a factor of increase of economic indicators of milk production on dairy complexes]. Veterynariia, tekhnolohii tvarynnytstva ta pryrodokorystuvannia, issue 2, pp. 150-154. doi: 10.31890/vttp.2018.02.39.

18. Shtainkhofel, S. and Pakhe, S., 2019. Menedzhment stada u vyroshchuvanni teliat [Management of herds in growing calves]. Kyiv: Ahrar Mediien Ukraina, p. 4.

19. Maklaxov, A., Abramova, N. and Burgomistrova, O., 2016. E'kster'er korov cherno-pestroj porody' na fermax $s$ intensivny 'mi texnologiyami [Exterior black and white cows on intensive technology farms]. Glavny”j zootexnik, issue 2, pp. 2328.

20. Gnoevoy, V., Hnoievyi, I. and Prudnykov, V., 2018. Fodder crops as promising sources of biologically active compounds in industrial livestock breeding. Agricultura, alimentaria, piscaria et zootechnica, issue 341, pp. 13-18.

21. GEA Farm, G., 2019. GEA Monobox Uniquely efficient - automated milking at any time. Bönen: GEA Farm Technologies GmbH. Retrieved from: https://www.gea.com/en/binaries/1602017_Monobox_LowRes_GB_529862_tcm11. 31184.pdf.

22. Gnoevoy, V., Hnoievyi, I. and Kotets, H., 2017. Productive and energetic evaluation of growing corn and soya mixture for silage. Scientific papers animal sciences. Seria zootehnie, issue 1, pp. 372-376.

23. Kandyba, V., Gnoevoy, V. and Hnoievyi, I., 2015. Innovative, soil-energysaving technology of the high valuable feeding and comfortable housing of highly productive animals for the modern farms and complexes of the XXI century. Kharkiv : Stil-Izdat, $332 \mathrm{p}$.

24. Kutchenrajter, V. and Grif, V. V mire doil'noj texniki [In the world of milking technology: translation from German]. http://mcx-consult.ru/page2309072009.

Bugayi Tetyana Anatoliyivna, chief technologist of the dairy complex "Vilshanske" Dvurichansky district, Kharkiv region

Gnoevyi Igor Viktorovich, Doctor of Agricultural Sciences, Professor, Kharkiv State Zooveterinary Academy

Naumenko Alexander Artemovich, Ph.D. of Technical Sciences, Professor, Kharkiv National Technical University of 
agriculture named after Petra Vasilenko

Gnoevyi Victor Ivanovich, Doctor of Agricultural Sciences, Professor, Kharkiv National Technical University of agriculture named after Petra Vasilenko

\section{Backgrounds for robotizing the cow milking process}

The work was carried out in the conditions of the Olshanskoye dairy complex in Dvurechansky district, Kharkiv region in 2018-2019, where excellent conditions were created for 500 highly productive cows of Ukrainian black-and-white dairy breed.As the objects for research, we used two GEA milking robots (Germany) serving 120 cows and a farm for 380 cows, which in 2011 was reconstructed for loose box housing for cows and fed from the feed table, watering from typical group drinkers. For milking the cows of the main herd, a Euroclass $2 \times 12$ «Fir-tree» milking unit was used. Before using milking robots, the dairy complex should be transferred to an effective industrial technology that ensures milk productivity of cows at the level of 10 thousand $\mathrm{kg} /$ year with a profitability of its production of $35-50 \%$. The primary task is to create our own complete, stable feed base on the basis of priority feed crops with the aim of producing per cow, on average, 116 GJOE and organize the same year-round feeding of feed mixtures, compiled according to detailed feeding standards for highly productive cows with costs per 1 centner of milk within 1.12 GJOE, including through concentrated feed 580-638 MJOE. The system of growing heifers should provide an average daily weight gain of $800 \mathrm{~g}$ for the entire growing period, including up to 6 months - $890 \mathrm{~g}$, to the year - $800 \mathrm{~g}$, older than $810 \mathrm{~g}$ with feed consumption per $1 \mathrm{~kg}$ of weight gain not more than 74.24 MJOE, including concentrated feeds - 24.36 MJOE. The use of milking robots does not increase the average daily milk yield of cows, but helps to reduce the cost of human labor, and their narrow feature - the mismatch of the length of time of milking and the duration of consumption of the selected compound feed, which must be borne in mind and make appropriate adjustments. The herd management system used at the Vilshanske dairy complex ensures the efficiency of milking robots at the cow productivity level in 2018, on average, $10556 \mathrm{~kg}$ and the profitability of its production within 34.4-43.7\% and the payback of milking robots 3 years and 10 months.

Key words: cows, milking, robots, organization, technology.

Дата надходження до редакції: 19.01.2020 р. 